\title{
Radial artery pseudoaneurysm: rare complication of a frequent procedure
}

\author{
Jose Paxiuta, ${ }^{1}$ Maria João Lobão, ${ }^{1}$ Liliana Carvalho ${ }^{2}$
}

${ }^{1}$ Hospital de Cascais, Cascais, Portugal

${ }^{2}$ Hospital de Egas Moniz, CHLO, Lisboa, Portugal

\section{Correspondence to} Dr Jose Paxiuta, josepaxiuta@gmail.com

Accepted 30 December 2016

\section{DESCRIPTION}

The pseudoaneurysms of the radial artery are uncommon, generally secondary to trauma or invasive procedures such as arterial catheterisation $(0.09 \%){ }^{12}$ Predisposing factors are advanced age, longer duration of catheterisation, coagulation disorders or use of anticoagulants/antiplatelet agents. A woman of 85 years, with history of ischaemic heart failure, chronic atrial fibrillation on anticoagulation, with labile International Normalisation Ratio, hypertension, peripheral artery disease and dyslipidaemia, was admitted in the context of acute pulmonary oedema secondary to hypertension, requiring hospitalisation in intermediate care unit and continuous arterial catheterisation. Seventeen days after removal of arterial line, a palpable pulsatile mass, soft, painless and without other inflammation signs was found at the site of palpation of the right radial artery, where previously the arterial catheter had been inserted (figures 1A, B). Further investigation by Doppler ultrasound (figure 1C) identified a pseudoaneurysm of the radial artery, $>2 \mathrm{~cm}$ in diameter, which was lap-permeable and non-thrombosed . No other complications, such as neurapraxia, compartment syndrome, rupture or haemorrhage were found until 38 days after

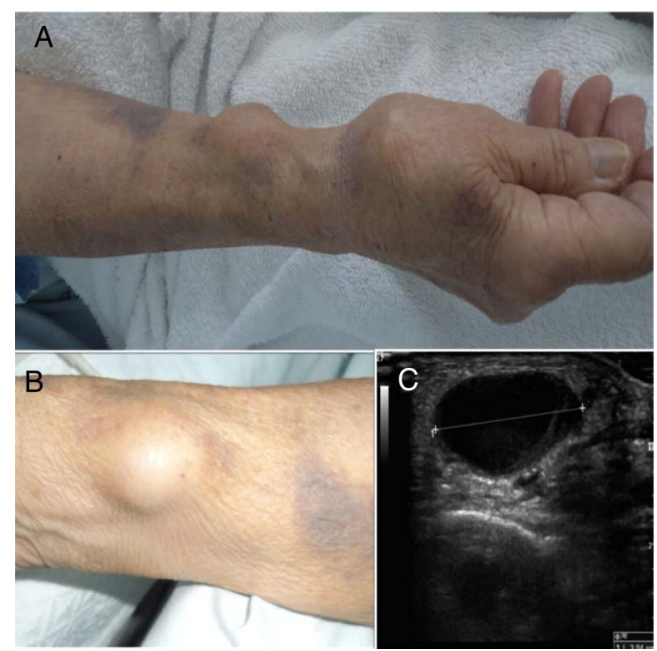

Figure 1 ( $A$ and $B$ ) Pulsatile mass, soft, painless and without other inflammation signs at the site of palpation of the right radial artery, where previously have been inserted the arterial catheter. (C) Ultrasound showing the pseudoaneurysm of the radial artery.

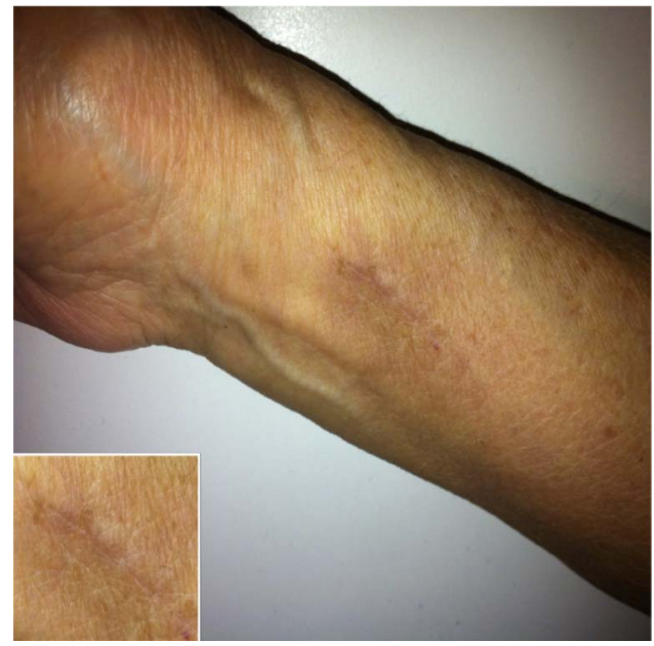

Figure 2 Wrist after surgical intervention.

diagnosis, when the patient was submitted to surgical removal of the false aneurysm and direct arteriorrhaphy, uneventfully (figure 2). To date, the patient is asymptomatic, with no evidence of any complication.

\section{Learning points}

- Illustrates a rare complication of a procedure commonly performed by the internist.

- Recalls the possibility of late development of pseudoaneurysm after arterial catheterisation.

Twitter Follow Jose Paxiuta @josepaxiuta

Contributors JP was responsible for the elaboration of the manuscript with collaboration of MJL. LC reviewed the paper.

Competing interests None declared.

Patient consent Obtained.

Provenance and peer review Not commissioned; externally peer reviewed.

\section{REFERENCES}

1 Poonai N, Lim R, Lynch T. Pseudoaneurysm formation following a traumatic wrist laceration. CJEM 2011;13:48-52.

2 Ranganath A, Hanumanthaiah D. Radial artery pseudo aneurysm after percutaneous cannulation using Seldinger technique. Indian J Anaesth 2011:55:274-6. 
Copyright 2017 BMJ Publishing Group. All rights reserved. For permission to reuse any of this content visit http://group.bmj.com/group/rights-licensing/permissions.

BMJ Case Report Fellows may re-use this article for personal use and teaching without any further permission.

Become a Fellow of BMJ Case Reports today and you can:

- Submit as many cases as you like

- Enjoy fast sympathetic peer review and rapid publication of accepted articles

- Access all the published articles

- Re-use any of the published material for personal use and teaching without further permission

For information on Institutional Fellowships contact consortiasales@bmjgroup.com

Visit casereports.bmj.com for more articles like this and to become a Fellow 